\title{
Constrições e possibilidades
}

Isaac Epstein*

VERÓN, Eliseo. Papeles en el tempo. Buenos Aires: Paidos, 2011. 309 p

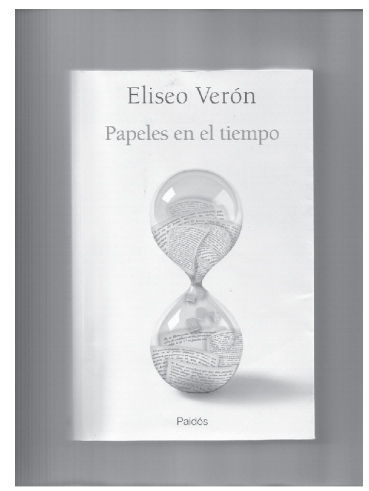

$\mathrm{O}$ livro de Eliseo Verón (Papeles en el tempo. Buenos Aires, Paidos, 2011) compõe-se de três partes. A primeira, denominada "Tiempos Y Escrituras", pode ser considerada como uma reflexão teórica sobre a dimensão temporal da atividade da escritura; a parte central é composta pela sequência de 81 textos de natureza jornalística com cerca de duas páginas cada um, que o autor publicou no jornal "Perfil" entre maio de 2008 e junho de 2011. A última parte, "Cuerpos Efimeros" tem algo de metalinguagem, tendo a parte central como linguagem objeto. Assim, o livro reúne formatos e conteúdos com características jornalísticas e acadêmicas.

"Tiempos e Escrituras" evocam, como diz o autor, a "dimensão temporal da atividade da escritura". Quanto à sua própria atividade de colunista, composta pela sequência mencionada de artigos, o autor distingue duas constrições: uma temporal: "Tem que entregar sua coluna a tal dia (cada quinze dias) e a tal hora". É um tempo distinto do tempo do pesquisador cujo prazo para a elaboração, é em geral, bem mais elástico. É uma diferença importante quando se pensa, por exemplo, no tempo do cientista e do divulgador da ciência. Trata-se do tempo disponível à reflexão e elaboração antes da ação (no caso a publicação), bem maior no caso do cientista do que do jornalista. De uma maneira mais geral entre o homem de pensamento e o homem de ação.

\footnotetext{
* Doutor em Ciências da Comunicação pela Universidade de São Paulo (USP). E-mail: isaacepstein@uol.com.br
} 
A segunda constrição é o espaço determinado pela editoria do veículo. No caso, 4200 a 4500 caracteres para cada artigo. A terceira constrição, o autor se impõe a si mesmo (uma vez que a editoria lhe deixava completa liberdade). O conteúdo da coluna deveria ter sua origem em algum acontecimento da atualidade imediata. Ora, uma fotografia geralmente revela um aspecto da realidade, mas este aspecto também revela algo do ideário seja artístico, social, cultural do fotógrafo. Também aqui, a escolha do autor das colunas revela algo sobre seu ideário através de sua escolha e seu modo de ver e interpretar o acontecimento da atualidade escolhido. $\mathrm{O}$ colunista escolhe o tema, restringido pelas regras da editoria e também por seu próprio arbítrio. Temos, então, um observador do mundo, o autor, que observa seu objeto e um segundo observador, que somos nós, e que podemos aferir, a partir de suas escolhas e opções interpretativas, algo sobre o autor.

A segunda parte é o corpo do livro propriamente dito. $\mathrm{O}$ que nos revelam as colunas? Uma boa parte versa sobre a política interna argentina. Nestes artigos o autor sempre é crítico, às vezes bem azedo, do casal Kirchner. Uma posição política, como outra qualquer, mas no caso perfeitamente alinhada com a do jornal que o contratou. Nada de extraordinário, e até bastante comum, que o jornalista opinativo alinhe sua posição com a do veículo que o contrata. O contrário é que seria altamente improvável e, portanto, altamente informativo.

Impossível, neste espaço analisar a variedade dos temas escolhidos, todos datados pela semana da publicação. O que têm em comum? Todos na limitação dada pelo espaço que lhes é alocado contam ou interpretam algo desta atualidade. Curto relato em linguagem densa que, na maioria dos casos, demanda do leitor um lastro cultural. Terminam sempre com uma pergunta, uma dúvida ou uma conclusão inesperada. Ao final, uma frase ou pouco mais, mas que instiga sempre uma reflexão em águas mais profundas. Que mais esperar de uma leitura casual de duas páginas de um jornal? Entre nós, onde isto também existe nos diários, mas em geral, como raridade de alguns cronistas, mergulhada num oceano de material redundante.

$\mathrm{Na}$ terceira parte do livro, "Los Cuerpos Efímeros", Veron opõe os "corpos densos" aos "corpos efêmeros" como modali- 
dades de suportes para o discurso escrito, este em oposição ao discurso oral típico da era pré-cristã, greco-romana. Os corpos densos, mas portáteis, como os livros se diferenciam dos corpos efêmeros que se subdividem, por sua vez, na família dos libelos, panfletos, folhetos, etc. São textos muito mais breves do que os livros e que tem uma unidade própria. A família específica dos almanaques caracterizada por um tempo cíclico é considerada como antepassada de uma publicação periódica típica da modernidade os newspapers que o autor literal e sugestivamente traduz por "papeis de notícias".

Esta repartição dos textos escritos, não quanto ao seu conteúdo, mas quanto ao seu suporte, é explorada pelo autor com bastante riqueza. A começar pelas famosas 95 teses de Luthero exibidas na porta da igreja do castelo de Wittenberg em 1517 e que rapidamente se divulgaram pela Alemanha e, a seguir, pela Europa. Luthero inaugurava um novo formato que rapidamente se expandiu pela Inglaterra e outros países. Na França o número de panfletos passa de 819 em 1788 a 3305 em 1789 .

Uma divisão em novas categorias de velhos objetos pode ser um prenúncio de análises originais e criativas. $O$ autor apenas aponta nesta série algumas possibilidades. Outras parecem possíveis. Por esta razão o texto de Verón nos parece uma leitura refrescante dentro da mesmice de um jornal aqui e, provavelmente, lá também. Recomendada, salvo melhor juízo, para qualquer um de nós, mas particularmente como um ótimo exercício de discussão, análise e interpretação em vários registros, por parte de alunos e professores de cursos de jornalismo.

O periódico Perfil bissemanal (sábados e domingos), de tendência liberal, é publicado em Buenos Aires desde 1998 e tem uma tiragem de cerca de 170.000 exemplares. Sua linha editorial pode ser considerada liberal e de centro.

$\mathrm{O}$ autor, Eliseo Verón, é dos mais importantes pesquisadores e autores latino-americanos no domínio das ciências da comunicação. Foi discípulo e colaborador de Levi Strauss, professor em universidades francesas e suas pesquisas abrangem tanto o âmbito acadêmico como às grandes empresas. Tem dezenas de livros e centenas de artigos publicados, desde a década de 1960. 